\title{
Implementasi Pembelajaran Pendidikan Agama Islam pada Anak Autis di Sekolah Luar Biasa Negeri Ciamis
}

\author{
Reni Rahmawati \\ Institut Agama Islam Darussalam (IAID), Ciamis-Jawa Barat \\ Email: reni_rahmawati@yahoo.com \\ Anis Husni Firdaus \\ Institut Agama Islam Darussalam (IAID), Ciamis-Jawa Barat \\ Selamet \\ Institut Agama Islam Darussalam (IAID), Ciamis-Jawa Barat
}

\begin{abstract}
This study aims to describe the learning outcomes of Islamic Religious Education for children with autism at the Ciamis Special School, namely as follows: 1) to determine the planning of Islamic Religious Education learning for children with autism in Ciamis State Special School; 2) to determine the implementation of Islamic Religious Education learning for children with autism in Ciamis State Special School; 3) to find out the evaluation of Islamic Religious Education learning for children with autism in Ciamis State Special School. This research uses a qualitative approach with a qualitative descriptive method. Collecting data using observation, interview, and documentation techniques. This research was conducted from March to May. The data sources were students with autistic special needs at the Ciamis Special School, while for complementary data the researchers conducted interviews and documentation studies. Then after the data is collected, it is followed by data reduction, presenting data, verifying data, and drawing conclusions. The results showed that: (1) Learning planning includes all aspects that support the implementation of the learning process. The learning process of PAI for children with autism in the Ciamis Special School School follows the 2013 curriculum with teacher modifications. The material presented is emphasized on practical material using various methods according to the needs of students. The learning process is guided by the educational components, namely: goals, educators, students, curriculum, materials, methods and evaluation, because all these components serve as benchmarks for adjusting the child's abilities, so that the desired learning objectives can be achieved. At the learning planning stage the teacher also prepares learning tools, namely the syllabus and lesson plans; (2) The implementation of Islamic Education learning for children with autism emphasizes character or moral education, various learning methods are used, tailored to the needs of students. The implementation of Islamic Education learning includes preliminary or apperception activities, core
\end{abstract}


activities, and closing activities. The time allocation for the implementation is 2 hours of lessons (2x35 minutes) and is held every Thursday from 07.30 to 08.40 WIB; (3) The evaluation carried out at Ciamis State Special School is carried out in three activities namely case evaluation, semester program evaluation and follow-up. The PAI learning results show that autistic children experience development / progress in carrying out religious rituals, as well as in living behavior as demands of their religion. This is shown like ablution, prayer, daily prayers and so on. Assessment standards and minimum completeness criteria (KKM) scores are set by the school.

Keywords: Islamic Religious Education, Autistic Children

\section{PENDAHULUAN}

Anak merupakan anugerah terindah yang Allah SWT titipkan kepada setiap pasangan orang tua. Oleh sebab itu, naluri setiap manusia mendambakan kelahiran seorang anak. Kelahiran dan kehadiran seorang anak membuat orang tua merasakan kebahagiaan yang luar biasa. Bahkan setiap orang tua berharap kelak anak tersebut tumbuh dan berkembang secara sempurna. Orang tua mengupayakan hal yang terbaik untuk perkembangan anak, termasuk dengan memberikan pendidikan yang terbaik. Namun, pada kenyataannya tidak semua anak terlahir ke dunia dengan sempurna, ada anak yang terlahir dengan memiliki beberapa keterbatasan atau lebih dikenal dengan anak berkebutuhan khusus (ABK). Anak autis termasuk ke dalam anak yang berkebutuhan khusus, karena anak autis mengalami gangguan perkembangan yang sangat kompleks yakni mulai dari gangguan dalam berbahasa, berkomunikasi, dan berinteraksi sosial dengan lingkungan sekitarnya.

Berdasarkan data dari UNESCO pada tahun 2011 tercatat 35 juta orang penyandang autisme di seluruh dunia. Ini berarti rata-rata 6 dari 1000 orang di dunia mengidap autisme. Sedangkan di Indonesia, pada tahun 2010, jumlah penderita autisme diperkirakan mencapai 2,4 juta orang. Hal itu berdasarkan data yang dikeluarkan oleh Badan Pusat Statistik. Pada tahun tersebut jumlah penduduk Indonesia mencapai 237,5 juta orang dengan laju pertumbuhan 1,14 persen. Jumlah penderita autisme di Indonesia diperkirakan mengalami penambahan sekitar 500 orang setiap tahun. Direktur Rehabilitasi Anak Kementerian Sosial Nahar menjelaskan, autisme dalam Undang-Undang (UU) Nomor 8 Tahun 2016 tentang Penyandang Disabilitas termasuk dalam penyandang disabilitas mental. Namun, berbeda data yang diungkap Kementerian PPPA, Nahar menyebut, penderita autisme di Indonesia pada 2015 diperkirakan mencapai 12.800 anak. Sedangkan 134.000 menyandang spektrum autisme. 


\section{BESTARI}

Vol. 17, No. 1, 2020

p-ISSN 1907-1337; e-ISSN 2807-6532

Dalam Al-Qur'an juga dijelaskan pada Q.S An-Nisaa' ayat 9:

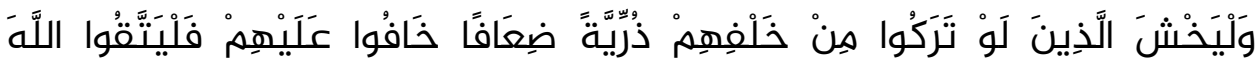

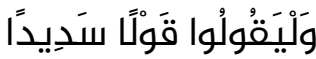

"Dan hendaklah takut (kepada Allah) orang-orang yang sekiranya mereka meninggalkan keturunan yang lemah dibelakang mereka, yang mereka khawatir terhadap (kesejahteraan) nya. Oleh sebab itu, hendaklah mereka bertakwa kepada Allah, dan hendaklah mereka berbicara dengan tutur kata yang benar" (Q.S An-Nisaa':9).

Semua orang baik normal maupun tidak normal mempunyai hak yang sama dalam memperoleh pendidikan. Bagi orang yang tidak normal atau berkebutuhan khusus, karena kelainan dan kekurangannya maka mereka memerlukan bantuan yang lebih banyak dalam menjalani kehidupan khususnya di bidang pendidikan. Sehingga mereka dapat melaksanakan kewajiban terhadap Allah SWT, masyarakat, dan dirinya sendiri.

Pada hakikatnya anak autis juga memerlukan pendidikan sebagaimana anak normal lainnya, karena sebenarnya anak autis juga mempunyai potensi yang dapat dikembangkan. Potensi-potensi tersebut dapat dimaksimalkan apabila mendapat penanganan yang tepat. Pada dasarnya peserta didik autis memiliki beberapa kecakapan dan kemampuan apabila guru mampu memberikan pelayanan pendidikan yang baik dan sesuai dengan kebutuhannya.

Solusi yang tepat bagi pendidikan anak berkebutuhan khusus ini adalah memberikan kesempatan kepada anak autis belajar di sekolah khusus, salah satunya yaitu di Sekolah Luar Biasa (SLB). Bentuk dukungan ini menjadikan anak autis menjadi pribadi yang mandiri. Sekolah khusus tersebut dapat membantu anak-anak tersebut untuk mengekspresikan dunia mereka.

\section{KAJIAN TEORI}

\section{Pengertian Pembelajaran}

Undang-Undang RI No. 11 Tahun 1980 tentang Sistem Pendidikan Nasional, menjelaskan bahwa pendidikan adalah hak dasar yang dimiliki oleh setiap manusia, tanpa terkecuali. Pendidikan Nasional bertujuan mencerdaskan bangsa dan mengembangkan manusia seutuhnya, yaitu manusia yang beriman dan bertaqwa terhadap Tuhan Yang Maha Esa dan berbudi pekerti luhur memiliki pengetahuan dan keterampilan, kesehatan jasmani dan rohani, kepribadian yang mantap dan mandiri serta rasa tanggung jawab kemasyarakatan dan kebangsaan. 
Secara yuridis anak berkebutuhan khusus (ABK) memiliki kedudukan dan hak yang sama dengan anak-anak normal pada umumnya dalam hal memperoleh pendidikan dan pengajaran tanpa membedakan kondisi tubuh atau jenis gangguannya. Dalam UU RI No. 20 Tahun 2003 tentang Sistem Pendidikan Nasional (SISDIKNAS) pasal 5 menetapkan sebagai berikut:

Ayat 1 "Setiap warga negara mempunyai hak yang sama untuk memperoleh pendidikan yang bermutu".

Ayat 2 "Warga negara yang memiliki kelainan fisik, emosional, mental, intelektual dan/atau sosial berhak memperoleh pendidikan khusus".

Ayat 3 "Warga negara di daerah terpencil atau terbelakang serta masyarakat adat yang terpencil berhak memperoleh pendidikan layanan khusus".

Ayat 4 "Warga negara yang memiliki potensi kecerdasan dan bakat istemewa berhak mendapatkan pendidikan khusus".

Ayat 5 "Setiap warga negara berhak mendapat kesempatan meningkatkan Pendidikan sepanjang hayat".

Menurut Undang-Undang Sistem Pendidikan Nasional (UUSPN) No. 20 Tahun 2003 pula, pembelajaran adalah proses interaksi peserta didik dengan pendidik dan sumber belajar pada suatu lingkungan belajar. Jadi, pada intinya proses pembelajaran tidak terlepas dari tiga hal, yaitu pendidik, peserta didik dan sumber-sumber belajar yang digunakan dalam proses pembelajaran.

Pembelajaran yang diidentikan dengan kata "belajar" berasal dari kata dasar "ajar" yang berarti petunjuk yang diberikan kepada orang supaya diketahui (diturut) ditambah awalan "pe" dan akhiran "an" menjadi "pembelajaran", yang berarti proses, perbuatan, cara mengajar atau mengajarkan sehingga anak didikmau belajar (Nurhalim, 2014: 25).

Prinsip-prinsip dalam pembelajaran meliputi: 1) disesuaikan dengan minat, kebutuhan dan kemampuan siwa, 2) siswa sebagai subyek pembelajaran, 3) keseimbangan aspek kognitif, afektif dan psikomotorik, 4) menggunakan sumber dan media yang bervariasi, 5) merupakan evaluasi proses maupun hasil belajar (Sukmadinata, 2007: 97).

Proses pembelajaran harus diupayakan dan selalu terkait dengan tujuan. Oleh karenanya, segala interaksi, metode dan kondisi pembelajaran harus direncanakan dan mengacu pada tujuan pembelajaran yang dikehendaki. Proses pembelajaran itu sendiri merupakan proses interaksi antara guru dengan siswa dan siswa dengan siswa yang mana di dalamnya banyak ditemukan aspek psikologis ketika proses pembelajaran berlangsung maka guru dituntut untuk memiliki pemahaman tentang psikologis guna memecahkan berbagai persoalan 


\section{BESTARI}

Vol. 17, No. 1, 2020

p-ISSN 1907-1337; e-ISSN 2807-6532

yang muncul dalam pembelajaran.

Salah satu mata pelajaran yang bertujuan untuk membentuk dan memberikan dasar-dasar pengetahuan agama Islam adalah Pendidikan Agama Islam (PAI). PAI secara umum memuat pengetahuan tentang agama Islam secara mendasar yang akan menjadi modal bagi siswa sebagai pengantar untuk mendalami ilmu agama Islam secara lebih jauh nantinya.

\section{Pengertian Pendidikan Agama Islam}

Menurut Zakiah Daradjat, Pendidikan Agama Islam atau AtTarbiyah Al-Islamiah adalah usaha bimbingan dan asuhan terhadap anak didik agar kelak stelah selesai pendidikannya dapat memahami dan mengamalkan ajaran agama Islam serta menjadikannya sebagai pandangan hidup (Daradjat, 1996: 86).

Pendidikan Agama Islam bertujuan untuk meningkatkan keyakinan, pemahaman, penghayatan, dan pengalaman siswa tentang agama Islam sehingga menjadi manusia muslim yang beriman dan bertaqwa kepada Allah SWT serta berakhlak mulia dalam kehidupan pribadi, bermasyarakat, berbangsa dan bernegara juga untuk melanjutkan pendidikan pada jenjang yang lebih tinggi (Ramayulis, 2005: 22).

Pendidikan Agama Islam sebagai bagian dari pendidikan, merupakan salah satu bidang studi di lembaga pendidikan umum dengan tujuan membantu peserta didik untuk memperoleh kehidupan yang bermakna, sehingga mereka mendapatkan kebahagiaan di dunia dan di akhirat, baik secara individu maupun kelompok. Pendidikan Agama Islam mengajari peserta didik tata cara berhubungan dengan sesama manusia, saling menghormati, menghargai dan menyayangi (Tafsir, 2001: 46).

Dari beberapa keterangan diatas, peneliti dapat menyimpulkan bahwasanya Pendidikan Agama Islam itu adalah pendidikan yang seluruh komponen atau aspeknya didasarkan pada ajaran agama Islam. Pembelajaran Pendidikan Agama Islam disini adalah upaya membelajarkan siswa atau peserta didik secara sadar dan terencana dalam menyiapkan siswa atau peserta didik untuk mengenal, memahami, dan menghayati hingga mengimami, bertaqwa dan berakhlak mulia dalam mengamalkan ajaran agama Islam dari sumber utamanya yakni dari kitab suci Al-Qur'an dan Hadits, yang prosesnya melalui kegiatan bimbingan, pengajaran, latihan serta penggunaan pengalaman untuk mencapai hasil yang diinginkan sebelumnya berdasarkan kondisi pembelajaran yang ada. Tujuan akhir mata pelajaran Pendidikan Agama Islam adalah terbentuknya peserta didik yang memiliki akhlak yang mulia. 


\section{Pengertian Autis}

Secara etimologis kata "autisme" berasal dari kata "auto" dan "isme". Auto artinya diri sendiri, sedangkan isme berarti suatu aliran atau paham. Dengan demikian autisme diartikan sebagai suatu paham yang hanya tertarik pada dunianya sendiri (Yuwono, 2009: 20).

Autisme pertama kali dijabarkan oleh Leo Kanner yang dikutip oleh Sherry Bonnice (2009), ia menggambarkannya sebagai gangguan penyempitan daya terima sensori seseorang, termasuk dalam berhubungan dengan orang lain. Batas lingkup autis ternyata sedemikian ekstrem, sehingga mereka tidak dapat melibatkan orang lain selain dirinya sendiri., anak-anak yang diteliti Kanner tidak mau melibatkan diri dalam kehidupan orang lain dan memberontak terhadap siapapun, termasuk orang tuanya sendiri, yang mengusik kehidupannya (Bonnice, 2009: 24- 25).

Autis terjadi pada 5 dari 10.000 kelahiran, dimana jumlah penderita laki-laki empat kali lebih besar dibandingkan penderita wanita. Meskipun demikian, bila kaum wanita mengalaminya, maka penderitaan akan lebih parah dibandingkan kaum pria. Gejala-gejala autism tampak sejak masa yang paling awal dalam kehidupan mereka. Gejala-gejala tersebut tampak ketika bayi menolak sentuhan orang tuanya, merespon kehadiran orangtuanya, dan melakukan kebiasaan-kebiasaan lainnya yang tidak dilakukan oleh bayi-bayi normal pada umumnya (Maulana, 2014: 15).

Faisal Yatim menyatakan bahwa autis bukan suatu gejala penyakit tetapi sindroma (kumpulan gejala) dimana terjadi penyimpangan perkembangan sosial, kemampuan berbahasa dan kepedulian terhadap dunia sekitar, sehingga anak autis seperti hidup dalam dunianya sendiri. Autis tidak termasuk golongan penyakit tetapi suatu kumpulan segala kelainan perilaku dan kemajuan perkembangan (Yatim, 2003: 11).

Autis atau biasa disebut dengan ASD (Autis Spectrum Disorder) merupakan gangguan perkembangan fungsi otak yang kompleks dan sangat bervariasi (spektrum). Biasanya, gangguan perkembangan ini meliputi cara berkomunikasi, berinteraksi sosial, dan kemampuan berimajinasi. Dari data para ahli, diketahui bahwa penyandang ASD anak lelaki empat kali lebih banyak dibandingkan penyandang ASD anak perempuan. Dengan kata lain, anak laki-laki lebih rentan menyandang sindrom autis dibandingkan anak perempuan (Prasetyono, 2008: 24).

Berdasarkan paparan definisi-definisi di atas, dapat ditarik kesimpulan bahwa autistik adalah gangguan perkembangan yang sangat komplek atau berat dalam kehidupan yang panjang, yang meliputi gangguan pada aspek perilaku, interaksi sosial, komunikasi dan bahasa, dan gejala ini terjadi pada usia sebelum 3 tahun. 


\section{BESTARI}

Vol. 17, No. 1, 2020

p-ISSN 1907-1337; e-ISSN 2807-6532

1. Ciri-ciri Anak Autis

Beberapa ciri-ciri anak autis sebagai berikut:

a. Perilaku

1) Cuek terhadap lingkungan

2) Perilaku tak terarah, mondar-mandir, lari-lari, manjatmanjat, berputar-putar, lompat-lompat dan sebagainya

3) Kelekatan terhadap benda tertentu

4) Perilaku tak terarah

5) Terpukau terhadap benda yang berputar dan bergerak

b. Interaksi sosial

1) Tidak mau menatap mata

2) Dipanggil tidak menoleh

3) Tidak mau bermain dengan teman sebayanya

4) Asyik/bermain dengan dirinya sendiri

5) Tidak ada empati dalam lingkungan sosial

c. Komunikasi dan bahasa

1) Terlambat bicara

2) Tidak ada usaha untuk berkomunikasi secara non-verbal dengan bahasa tubuh

3) Meracau dengan bahasa yang tak dapat dipahami

4) Membeo (Echolalia)

5) Tak memahami pembicaraan orang lain (Yuwono, 2009: 25).

d. Perasaan atau Emosi

1) Tidak ada atau kurangnya rasa empati

2) Tertawa-tawa sendiri, menangis atau marah-marah tanpa sebab yang diketahui

3) Sering mengamuk tak terkendali (Temper Tantrum), terutama bila tak mendapatkan apa yang diinginkan, bahkan bisa jadi sangat agresif dan destruktif.

e. Persepsi Sensoris

1) Mencium-cium, menggigit atau menjilat mainan dan benda apa saja

2) Bila mendengar suara keras langsung menutup telinga

3) Tak menyukai rabaan atau pelukan

4) Merasa tidak nyaman bila tidak memakai pakaian dari bahan kasar (Mulyadi dan Sutadi, 2014: 18).

\section{Faktor Penyebab Autis}

Penelitian menunjukkan, banyak faktor mempengaruhi perkembangan otak anak autistik, yang terjadi sejak usia 6 bulan dalam kandungan, dan terus berlanjut dalam kehidupannya. Dengan bertambahnya usia anak, akan semakin besar perbedaan kemampuannya dibanding anak lain seumurnya. Semua ini terlihat jelas sebelum anak berusia 3 tahun kasar (Mulyadi dan Sutadi, 2014: 12). 
Menurut Melly Budiman yang dikutip oleh Agus Suryana (2004), penyebab autis adalah adanya gangguan pada perkembangan susunan saraf pusat yang mengakibatkan fungsi otak terganggu. Autis bisa terjadi pada siapa saja. Perbandingan antar laki-laki dan perempuan diperkirakan 3 berbanding 1 . Seorang ibu yang cermat memantau perkembangan anaknya akan mudah melihat beberapa keganjilan sebelum anaknya mencapai usia satu tahun. Dan yang sangat menonjol adalah sangat kurangnya kontak dengan mata. Sedangkan menurut Faisal Yatim, pendapat yang menjadi konsensus bersama para ahli belakangan ini mengakui bahwa autis diakibatkan menjadi kelainan fungsi luhur di dalam otak. Kelainan fungsi ini bisa disebabkan oleh:

a. Trauma sewaktu bayi dalam kandungan, misalnya mereka karena keracunan kehamilan, infeksi virus rubella, virus cytomegalo dan lainnya.

b. Kejadian segera setelah lahir, seperti kekurangan oksigen (anoksia).

c. Keadaan selama kehamilan seperti pembentukan otak yang kecil, misalnya vermis otak kecil yan lebih kecil atau terjadi pengerutan jaringan otak.

d. Kemungkinan terjadi kelainan metabolism seperti pada penyakit Addison, dimana bertambahnya pigmen tubuh dan kemunduran mental (Suryana: 2004: 18).

3. Jenis Autis

Berikut adalah lima jenis autis menurut Autism Society of Amecira:

1) Sindrom Asperger: jenis gangguan ini ditandai dengan devisiensi interaksi sosial dan kesulitan dalam menerima perubahan rutinitas sehari-hari. Pada sindrom asperger, kemampuan bahasa tidak terlalu terganggu bila dibandingkan dengan gangguan lain. Anak yang menderita jenis autis ini kurang sensitif terhadap rasa sakit, namun tidak dapat mengatasi paparan suara keras dan sinar lampu secara tiba-tiba. Anak dengan sindrom asperger memiliki kecerdasan rata-rata atau diatas rata-rata sehingga secara akademik mampu dan tidak bermasalah.

2) Autis Disorder: disebut sebagai Chilhood autism karena sebagian besar berkembang pada tiga tahun awal usia anak. Anak yang terkena pada jenis autis ini tidak memiliki kemampuan bicara dan hanya tergantung pada komunikasi verbal. Kondisi ini mengakibatkan anak menarik diri secara ekstrim terhadap lingkungan sosialnya dan bersikap acuh-tak acuh. Pada gangguan ini, keterampilan verbal dan non verbal cenderung terbatas sehingga anak kurang bisa berkomunikasi (Kurniati, 2012: 6).

3) Pervasif Development Disorder: autis jenis ini meliputi berbagai jenis gangguan dan tidak spesifik terhadap satu gangguan. Tingkat 


\section{BESTARI}

Vol. 17, No. 1, 2020

p-ISSN 1907-1337; e-ISSN 2807-6532

keparahan mulai dari yang ringan sampai ketidakmampuan yang ekstrim umumnya didiagnosis dalam 5 tahun usia pertama anak.

4) Chilhood Disintegrative Disorder: gejala gangguan ini muncul ketika seorang anak berusia antara 3-4 tahun. Pada dua tahun awal, perkembangan anak nampak normal namun yang kemudian terjadi regresi mendadak dalam komunikasi, bahasa, sosial, dan keterampilan motorik. Anak menjadi kehilangan semua keterampilan yang dia peroleh sebelumnya dan mulai menarik diri dari lingkungan sosial.

5) Reet Syndrome: jarang ditemukan dan sering keliru didiagnosis sebagai autis. Sindrom ini mempengaruhi perempuan dewasa atau anak perempuan yang ditandai oleh pertumbuhan kepala yang abnormal. Penyebabnya adalah mutasi pada urutan sebuah gen tunggal. Gejala awal yang teramati diantaranya kehilangan kontrol otot yang menyebabkan masalah dalam berjalan dan mengontrol gerakan mata. Keterampilan motorik terlambat dan mengganggu setiap gerakan tangan dan kaki yang berulang (Kurniati, 2012: 7).

\section{METODE}

Penelitian ini menggunakan jenis penelitian kualitatif, dan metode yang digunakan dalam penelitian ini adalah metode penelitian deskriptif. Secara spesifik penelitian ini berkenaan dengan implementasi pembelajaran Pendidikan Agama Islam pada anak autis di SLB Negeri Ciamis. Adapun pendekatan yang digunakan dalam penelitian ini adalah pendekatan studi kasus.

Pendekatan yang digunakan dalam penelitian ini adalah dengan menggunakan pendekatan kualitatif lapangan (field research) yang bersifat evaluatif, yaitu penelitian yang dimaksudkan untuk mengukur keberhasilan suatu program, produk, atau kegiatan tertentu. Peneliti langsung terjun ke lapangan dan ikut serta dalam kegiatan sehari-hari bersama-sama dengan subjek penelitian serta mengamati langsung persoalan-persoalan yang terjadi, peneliti mengumpulkan data sebanyakbanyaknya dari sumber yang berbeda-beda. Peneliti melihat fenomena dan peristiwa yang terjadi sebenarnya dan membuktikan kebenaran sebenarnya kejadian yang terjadi. Kemudian peneliti mengadakan observasi terhadap subjek penelitian dalam pembelajaran Pendidikan Agama Islam pada anak autis di SLB Negeri Ciamis yang berlokasi di jalan Jenderal Sudirman No. 191, Kelurahan Sindangrasa, Kecamatan Ciamis, Kabupaten Ciamis. Adapun teknik dan instrumen pengumpulan data yang digunakan dalam penelitian ini menggunakan beberapa metode, yaitu observasi (pengamatan), wawancara, dan dokumentasi. 


\section{HASIL PENELITIAN}

Setelah mengadakan penelitian pada bulan Maret - Mei 2019 di SLB Negeri Ciamis, peneliti berusaha mengumpulkan data sebanyakbanyaknya, baik data dokumentasi, foto-foto atau gambar, hasil wawancara, maupun data dari hasil proses pembelajaran. Selanjutnya peneliti menganalisis dan mengolah data-data tersebut sebagai bahan dalam penyusunan skripsi.

Sekolah Luar Biasa (SLB) Negeri Ciamis berdiri pada tahun 1968 beralamat di Jl. Jenderal Sudirman No. 191, Kelurahan Sindangrasa, Kecamatan Ciamis, Kabupaten Ciamis, Kode Pos 46215. Telp. （O265) 774253/775148, e-mail slbn_031jabar@yahoo.com. Sekolah Luar Biasa (SLB) Negeri Ciamis berstatus sekolah Negeri dengan nomor NSS 80.1.02.14.18.00, NIS 02202, NPSN 20263125, NPWP 20.025.646.9442.000, Izin Operasional/ Penegerian dari DIRJEN DIKDASMEN, Nomor: C. 2545/Set/Prasar VIII/68, tanggal 14 September 1968. Waktu penyelenggaraan SLB Negeri Ciamis adalah pagi.

Adapun program unggulan di Sekolah Luar Biasa Negeri Ciamis diantaranya adalah keterampilan vokasional menjahit, tata kecantikan, olahraga, kesenian, desain grafis, tata boga. Sedangkan status akreditasinya sebagai berikut: 1) SDLB Terakreditasi A Tahun 2014, 2) SMPLB Terakreditasi A Tahun 2015, 3) SMALB Terakreditasi A Tahun 2013.

Berdasarkan hasil dokumentasi data yang ada di Sekolah Luar Biasa Negeri Ciamis, siswa yang bersekolah di Sekolah Luar Biasa Negeri Ciamis meliputi anak-anak yang berkebutuhan khusus jumlah keseluruhannya yaitu 168 siswa yang terdiri dari jenjang SDLB, SMPLB, dan SMALB. Adapun setiap jenjang memiliki kelas-kelas khusus sesuai dengan kebutuhan anak berkebutuhan khusus, yaitu terdiri dari kelas tuna netra, tuna rungu, tuna grahita, tuna grahita sedang, tuna daksa, tuna ganda, dan anak autis.

Peserta didik autis di Sekolah Luar Biasa Negeri Ciamis terdapat 4 siswa, semuanya berada di kelas yang berbeda-beda, 3 siswa diantaranya berjenjang SDLB sedangkan 1 siswa berada pada jenjang SMPLB. Siswasiswa Sekolah Luar Biasa (SLB) Negeri Ciamis berasal dari beberapa daerah diantaranya dari Kabupaten Ciamis, Kabupaten dan Kota Tasikmalaya, Kota Banjar, Kabupaten Pangandaran dan berbagai daerah lainnya. Untuk siswa-siswa yang datang dari luar Kabupaten Ciamis disediakan asrama yang aman dan nyaman yang masih berada di kawasan gedung sekolah. Sedangkan keadaan guru-guru di SLB Negeri Ciamis tahun pelajaran 2018/2019 berjumlah 62 orang, tenaga administrasi/ TU berjumlah 11 orang, dan caraka berjumlah 3 orang. 
BESTARI

Vol. 17, No. 1, 2020

p-ISSN 1907-1337; e-ISSN 2807-6532

\section{PEMBAHASAN}

Penelitian ini akan membahas mengenai perencanaan pembelajaran, pelaksanaan pembelajaran, dan evaluasi pembelajaran Pendidikan Agama Islam pada anak autis di Sekolah Luar Biasa Negeri Ciamis. Peneliti melakukan wawancara terhadap beberapa informan di Sekolah Luar Biasa (SLB) Negeri Ciamis, informan tersebut antara lain:

1. Drs. Ade Rosyid Rustandi, M. Pd, selaku Kepala Sekolah Luar Biasa Negeri Ciamis.

2. H. Ayi Sulaeman, S. Pd, selaku guru mata pelajaran PAI SLB Negeri Ciamis.

3. Novia Alfiatul Fiqri, S. Pd, selaku guru kelas khusus autis SLB Negeri Ciamis.

Menurut hasil wawancara peneliti dengan guru kelas khusus anak autis Ibu Novia Alfiatul Fiqri, beliau memaparkan:

"Pada tahun ajaran 2019, jumlah anak autis untuk jenjang SDLB ada 4 orang siswa, sedangkan dalam satu kelas untuk jenjang SMPLB terdapat 1 peserta didik, dan pada jenjang SMALB tidak ada siswa yang menyandang autis. Adapun untuk guru, pada setiap kelas mempunyai guru kelas khusus autis/ guru khusus pendamping, dan guru untuk masing-masing mata pelajaran bidang studi”.

Pembelajaran Pendidikan Agama Islam pada anak autis adalah proses interaksi anak autis dengan pendidik dan sumber belajar pada suatu lingkungan belajar untuk megembangkan fitrah keberagaman anak autis agar mampu memahami, menghayati, dan mengamalkan ajaran Islam melalui kegiatan bimbingan, pengajaran, dan latihan.

Seperti yang diungkapkan oleh bapak Ayi Sulaeman dalam wawancara, beliau menyatakan bahwa:

"Dalam pelaksanaan pembelajaran Pendidikan Agama Islam untuk anak yang berkebutuhan khusus, terutama anak autis, memang merupakan suatu pembelajaran yang cukup sulit, namun walau bagaimanapun mereka juga perlu bahkan harus tetap diberi pelajaran Pendidikan Agama Islam, karena pelajaran Pendidikan Agama Islam merupakan hal yang penting dalam kehidupan untuk bekal mereka di masa mendatang".

Dari pernyataan di atas menunjukkan bahwa pembelajaran Pendidikan Agama Islam untuk anak autis sangatlah penting untuk anak dalam perkembangan berkomunikasi dan bersosialisasi dengan lingkungan sekitarnya. Bapak Ayi menyebutkan bahwa ada tiga hal dasar yang dijadikan fundamen yang harus terbentuk untuk dijadikan jaminan 
mereka mendapatkan belajar dengan baik, tiga hal tersebut adalah:

a. Kepatuhan

Seorang anak autis yang sudah tertera kepatuhannya dengan baik akan melebihi kepatuhan anak normal pada umumnya karena pendidikan yang diterima pertama ini akan membentuk dirinya untuk melaksanakan kewajibannya. Dalam membentuk kepatuhan pada anak autis para pengajar melatihnya dengan memberikan perintah (instruksi), yang harus dilakukan, berdoa sebelum melakukan kegiatan, dan lain-lain.

b. Kontak mata

Anak autis sebagaimana telah dijelaskan diatas cenderung bersikap cuek, maka agar anak autis fokus memperhatikan harus melihat benda yang sedang diperhatikan mulai dari bentuknya besar sampai yang kecil, di samping itu anak-anak autis susah dalam menginterpretasikan sesuatu. Contoh: dalam mengetahui warna, melihat benda dan lain-lain.

c. Konsentrasi

Dalam belajar harus konsentrasi agar apa yang disampaikan dapat terserap dengan baik oleh otak. Maka dari itu bila anak-anak mempunyai konsentrasi yang tinggi mudah dalam belajar. Namun bagi anak-anak autis untuk membentuk konsentrasi pada mereka dengan contoh: anak disuruh memperhatikan benda yang bergerak, ke kanan ke kiri, atas maupun ke bawah, kemudian disuruh menirukan huruf hijaiyah, dan lain-lain.

Di samping itu untuk mendukung agar tiga hal pokok dapat terlaksana ada beberapa hal yang perlu diperhatikan, lebih-lebih bagi guru dalam proses pembelajaran di antaranya yaitu:

1. Suara jelas, tidak monoton.

2. Setiap intruksi harus sama antar guru.

3. Pemberian instruksi harus jelas, singkat (kalimat pendek) dan bahasa sederhana.

Begitu pentingnya pendidikan bagi anak autis, maka alasan yang tepat dalam upaya memberikan pelajaran bagi mereka adalah untuk memanusiakan mereka dengan memberikan layanan yang baik secara pendidikan atau tidak. Bukan satu tujuan yang mudah, kenyataan di lapangan banyak macam dan kondisi mereka yang bervariatif, tantangan yang terbentang begitu luas dan lebar sehingga banyak cara dan ragam penanganan mereka. Dalam pelaksanaannya peneliti memfokuskan pengamatan pada proses pembelajaran Pendidikan Agama Islam pada anak autis.

Untuk lebih jelasnya hasil wawancara peneliti dengan berbagai 
BESTARI

Vol. 17, No. 1, 2020

p-ISSN 1907-1337; e-ISSN 2807-6532

informan, mengenai implementasi pembelajaran Pendidikan Agama Islam pada anak autis peneliti uraikan seperti dibawah ini:

1. Perencanaan Pembelajaran Pendidikan Agama Islam pada anak autis di SLBN Ciamis

Menurut hasil wawancara dengan Kepala Sekolah Sekolah Luar Biasa Negeri Ciamis yaitu Bapak Ade Rosyid Rustandi, beliau memaparkan:

"Perencanaan pembelajaran disusun oleh guru mulai dari membuat Rencana Pelaksanaan Pembelajaran (RPP), program semester (prosem) sampai pada penentuan tema, subtema, indikator, kegiatan pembelajaran serta media yang di buat mengacu pada kurikulum 2013 yang akan ditinjau kembali oleh guru dan kepala sekolah untuk diseleksi dan dievaluasi, kemudian akan dimodifikasi yang disesuaikan dengan kondisi, kebutuhan dan kemampuan anak autis".

Berbicara mengenai perencanaan pembelajaran Pendidikan Agama Islam yang diterapkan di SLB Negeri Ciamis, perencanaan pembelajaran merupakan suatu upaya untuk menentukan kegiatan yang akan dilakukan dalam kaitan dengan upaya mencapai kompetensi yang diharapkan. Seorang guru dalam merencanakan pembelajaran harus membuat perangkat pembelajaran meliputi:

1. Silabus

Silabus merupakan rancangan pembelajaran yang berisi rencana bahan ajar mata pelajaran tertentu pada jenjang dan kelas tertentu, sebagai hasil dari seleksi, pengelompokan, pengurutan, dan penyajian materi kurikulum yang dipertimbangkan berdasarkan ciri dan kebutuhan daerah setempat. Silabus merupakan penjabaran lebih rinci dan Standar Kompetensi dan Kompetensi Dasar (SKKD) yang minimal memuat kompetensi dasar, materi standar, dan hasil belajar yang harus dimiliki oleh peserta didik sehubungan dengan mata pelajaran. Adapun komponen silabus yang dibuat oleh guru PAI SLB Negeri Ciamis meliputi:

a. Standar kompetensi dan kompetensi dasar (SKKD);

b. Materi standar;

c. Kegiatan pembelajaran;

d. Indikator;

e. Penilaian;

f. Alokasi waktu, dan

g. Sumber belajar. 


\section{Rencana Pelaksanaan Pembelajaran (RPP)}

Tugas utama guru dalam kaitannya dengan dokumen kurikulum adalah membuat rencana pembelajaran yang akan dijadikan pedoman pelaksanaan pembelajaran dan pembentukan kompetensi peserta didik. Perencanaan merupakan bagian penting yang harus diperhatikan dalam implementasi kurikulum yang digunakan, yang akan menentukan kualitas pembelajaran secara keseluruhan dan menentukan kualitas pendidikan serta kualitas sumber daya manusia, baik di masa sekarang maupun di masa depan. Oleh karena itu, dalam kondisi dan situasi bagaimanapun, guru tetap harus membuat rencana pelaksanaan pembelajaran (RPP), karena perencanaan merupakan pedoman pembelajaran. Adapun komponen rencana pelaksanaan pembelajaran yang dibuat oleh guru PAI SLB Negeri Ciamis meliputi:

a. Identitas mata pelajaran, terdiri dari: nama mata pelajaran, kelas, semester, dan waktu.

b. Standar kompetensi, merupakan kualifikasi kemampuan minimal peserta didik yang menggambarkan penguasaan sikap, pengetahuan dan keterampilan yang diharapkan dicapai pada setiap tingkat atau semester.

c. Kompetensi dasar, yakni sejumlah kemampuan yang harus dimiliki peserta didik dalam mata pelajaran tertentu sebagai rujukan menyusun indikator kompetensi.

d. Indikator pencapaian kompetensi adalah karakteristik ciri-ciri, tanda-tanda perbuatan, respon yang harus dapat dilakukan oleh peserta didik.

e. Tujuan pembelajaran, merupakan hasil minimal yang harus dikuasai peserta didik.

f. Materi pokok pelajaran.

g. Metode, merupakan pendekatan yang dilakukan dalam mencapai tujuan pembelajaran secara efektif dan efisien.

h. Alat dan media, ini untuk memperlancar pencapaian serta sebagai sumber bahan yang digunakan selama perjalanan.

i. Evaluasi dan tindak lanjut adalah prosedur dan instrument yang akan digunakan untuk menilai pencapaian belajar peserta didik serta tindak lanjut hasil penilaian.

3. Kurikulum Pendidikan Agama Islam pada Anak Autis di SLB Negeri Ciamis 


\section{BESTARI}

Vol. 17, No. 1, 2020

p-ISSN 1907-1337; e-ISSN 2807-6532

Kurikulum Pendidikan Agama Islam merupakan alat untuk mencapai tujuan Pendidikan Agama Islam. Untuk mencapai tujuan tersebut, maka kurikulum Pendidikan Agama Islam harus sesuai dengan tujuan agama Islam, tingkat usia, perkembangan kejiwaan, dan kemampuan peserta didik yang belajar Pendidikan Agama Islam. Dalam hal ini, kurikulum pembelajaran Pendidikan Agama Islam pada anak autis di SLB Negeri Ciamis yakni kurikulum 2013 yang dirancang sederhana sesuai dengan batas-batas kemampuan peserta didik. Muatan isi mata pelajaran SLB Negeri Ciamis pada dasarnya sama dengan sekolah umum, akan tetapi dipilih, dimodifikasi dan dikembangkan oleh guru dengan bertitik tolak pada kebutuhan masing-masing anak autis berdasarkan identifikasi.

\section{Pelaksanaan Pembelajaran Pendidikan Agama Islam pada Anak Autis di SLBN Ciamis}

Dari hasil wawancara peneliti dengan guru mata pelajaran PAI yaitu Bapak Ayi Sulaeman dan hasil pengamatan melalui observasi proses pembelajaran Pendidikan Agama Islam di SLB Negeri Ciamis pada siswa autis, alokasi waktu pelaksanaannya yaitu 2 jam pelajaran (2x35 menit) dan dilaksanakan setiap hari Kamis pada pukul 07.30 sampai dengan pukul 08.40 WIB. Waktu yang digunakan sama dengan alokasi waktu pembelajaran sekolah umum lainnya, hanya saja dalam praktiknya menyesuaikan dengan kondisi yang terjadi di dalam kelas dan berdasarkan dengan kebutuhan peserta didik, karena pembelajaran pada peserta didik autis sifatnya fleksibel dan tidak bisa dipaksakan. Pada setiap pokok bahasan dicantumkan alokasi waktu yang dapat dipergunakan untuk menyajikan bahan atau materi pelajaran setiap pokok bahasan atau sub bahasan tersebut.

Pembelajaran selalu diawali dengan mengucapkan salam dan dilanjutkan berdo'a bersama-sama di ruangan kelas setiap pagi sebelum pelajaran dimulai yang dibacakan/ dipimpin oleh guru PAI (do'a pembuka) lalu diikuti oleh setiap peserta didik, setelah itu guru menanyakan kabar kepada peserta didik, memperkenalkan bahan ajaran atau materi yang akan disampaikan.

Menurut hasil wawancara dengan guru mata pelajaran PAI Bapak Ayi Sulaeman, beliau memaparkan:

"Materi yang diajarkan di dalam pelajaran Pendidikan Agama Islam meliputi Akhlak, Al-Qur'an, Akidah, Sejarah, dan Fiqh, namun saya lebih menekankan kepada Akhlak atau pendidikan karakter dimana siswa diharapkan dapat selalu membiasakan sifat terpuji agar menjadi bekal di masa depannya kelak. Siswa autis diharapkan mampu merefleksikan materi yang dipelajarinya ke dalam kegiatannya sehari-hari melalui berbagai pembiasaan dan pengulangan-pengulangan. Seperti mengucapkan salam dan 
tersenyum ketika bertemu dengan oranglain, mengucap salam ketika masuk ke ruangan kelas dan ketika hendak memulai pelajaran, melaksanakan wudhu dan shalat dhuha serta shalat dzuhur, melaksanakan kegiatan amal dan sedekah setiap hari jum'at, serta mampu membacakan surah-surah pendek. Adapun untuk proses pembelajaran PAI, guru membagi waktu belajar menjadi tiga kategori, yakni: kegiatan pendahuluan atau apersepsi, kegiatan inti, dan kegiatan penutup.”

a. Kegiatan apersepsi atau pendahuluan

Guru mengawali dengan membaca do'a belajar dan menanyakan kabar peserta didik. Sebelum menjelaskan materi, guru memberikan ujian pramateri (pre-test) dan mengulas sedikit materi minggu lalu kepada peserta didik. Fungsi dari ujian pramateri (pre-test) tersebut untuk mengetahui kemampuan peserta didik terhadap pembelajaran yang akan dilaksanakan. Oleh karena itu, ujian pramateri (pre-test) memegang peranan yang cukup penting dalam pelaksanaan pembelajaran.

Dalam menyampaikan materi guru menggunakan metode ceramah tidak menggunakan teks book. Materi yang sama bisa diajarkan dalam beberapa kali atau berulang-ulang untuk mendapatkan respon yang lebih baik dari peserta didik. Sebagaimana ungkapan dari Bapak Ayi selaku guru mata pelajaran PAI di SLB Negeri Ciamis, bahwasanya peserta didik anak berkebutuhan khusus dalam memahami materi pelajaran harus dilakukan secara berulang-ulang. Agar ingatan dalam diri peserta didik lebih kuat, serta dapat membantu peserta didik untuk lebih memahami materi PAI yang telah disampaikan. Seperti pada pembahasan melafalkan surat pendek pilihan, guru membacakan Qur'an Surat Al-Ashr dan menjelaskan arti kandungannya, setelah itu peserta didik diminta untuk menirukan kembali lafal Qur'an Surat Al-Ashr dengan lancar, di lain waktu guru juga akan meminta mengulangi lagi melafalkan surat-surat pendek lain yang sudah pernah diajarkan sebelumnya, sehingga anak menjadi lancar dan hafal.

b. Kegiatan inti

Guru menjelaskan pengertian dzikir memberikan ceramah ringan mengenai dzikir, melafalkan bacaan dzikir seperti istighfar, tahlil, tahmid, tasbih beserta lafadznya lalu peserta didik diajak untuk mengucapkannya bersama-sama, guru menjelaskan berapa kali dzikir itu dibaca dan menjelaskan perumpamaan orang yang setelah shalat tidak berdzikir terlebih dahulu. Kemudian dilanjutkan guru menjelaskan pengertian do'a, macam-macam do'a, dan meminta peserta didik memberikan salah satu contoh do'a, guru memberikan ceramah mengenai do'a yang seharusnya sering 


\section{BESTARI}

Vol. 17, No. 1, 2020

p-ISSN 1907-1337; e-ISSN 2807-6532

kita baca dalam kehidupan sehari-hari seperti: do'a untuk kedua orang tua, do'a sebelum dan sesudah makan, do'a sebelum dan sesudah bangun tidur dan lain-lain.

Setelah itu guru memberikan latihan soal dengan permainan menggunakan kartu (Index Card Match) yakni guru memberikan potongan-potongan kartu kecil yang bertuliskan macam-macam lafadz dzikir beserta bacaan dan artinya, kartu dikocok lalu peserta didik disuruh untuk mencocokkan antara lafadz dan artinya. Metode ini dapat mengasah pengetahuan, keterampilan dan kekompakan peserta didik. Selanjutnya guru memeriksa kecocokan jawaban kartu tersebut.

c. Kegiatan penutup

Dalam kegiatan penutup gguru menanyakan kembali materi yang telah disampaikan untuk mengetahui sejauh mana pemahaman peserta didik, guru membacakan kesimpulan dari materi dzikir dan do'a yang telah disampaikan, guru menutup pelajaran dengan berdoa dan salam.

Selain pembelajaran di dalam kelas, peserta didik juga selalu diajarkan untuk melakukan shalat dhuha dan shalat dzuhur berjama'ah di masjid. Selain untuk menerapkan pendidikan karakter, juga untuk melatih kedisiplinan peserta didik, yang dimana guru mengharapkan hal tersebut menjadi pembiasaan yang akan terus dilakukan dalam kehidupan sehari-hari peserta didik. Mereka juga dilatih untuk wudhu sebelum shalat, dan diajarkan membasuh seluruh anggota wudhu dengan benar sebelum dilaksanakannya shalat berjama'ah.

Dalam pelaksanaannya, pembelajaran PAI pada anak autis di SLBN Ciamis tidak terfokus pada penggunaan satu metode saja, melainkan didalamnya merupakan kombinasi antara satu metode dengan metode yang lain. Metode yang diterapkan dalam proses pembelajaran PAI di SLB Negeri Ciamis sebagai berikut:

1) Metode Ceramah

2) Metode Konsep Belajar Sosial yakni modeling (pemberian contoh), role playing (permainan peran), dan rahersal (latihan/pengulangan).

3) Metode Tanya Jawab

4) Metode Demonstrasi

5) Metode Karya Wisata, seperti halnya di SLB Negeri Ciamis guru PAI mengajak peserta didiknya untuk belajar di luar ruang kelas disesuaikan dengan materi yang diajarkan seperti dalam materi 
praktik wudhu dan shalat, selain itu supaya peserta didik tidak jenuh dalam proses pembelajaran.

6) Metode Drill

7) Metode Operan Conditioning, dalam metode ini jika peserta didik melakukan kesalahan mendapatkan konsekuensi hukuman dengan membaca istighfar dengan jumlah yang telah ditentukan guru PAI tersebut, jika peserta didik berperilaku positif guru memberikan pujian maupun hadiah tertentu.

Metode yang khusus dalam pembelajaran Pendidikan Agama Islam pada anak autis dengan bermain, biasanya menggunakan dalam bentuk alat peraga kongkrit, karena anak autis untuk target akademik belum bisa tapi lebih kepada keterampilan melalui pembiasaan untuk kemandirian. Hasil dari pembelajaran PAI yang diperoleh peserta didik penyandang autis yakni, mereka sudah dapat membaca dan menghafal dengan benar surah-surah pendek pilihan seperti surah Al-Fatihah, Al-Falaq, Al-Ikhlas, Ad-Dhuha, An-Nas dan lain-lain. Serta do'a-do'a pilihan, do'a sebelum dan sesudah makan, tidur, masuk dan keluar kamar mandi, doa belajar serta do'a untuk kedua orang tua dengan lancar dan benar yang diaplikasikan dalam kehidupan sehari-hari. Peserta didik dapat membedakan perilaku yang baik dan buruk, membiasakan perilaku terpuji yakni dengan setiap akan berangkat ke sekolah berpamitan cium tangan kedua orang tua, sebelum dan selesai pembelajaran bersalaman dengan mencium tangan guru atau staf pengajar di sekolah.

Adapun problematika dalam pelaksanaan pembelajaran Pendidikan Agama Islam di SLBN Ciamis sangat beragam, namun permasalahan yang mendasar yaitu adanya kesulitan peserta didik dalam memahami materi, hal ini terjadi karena keterbatasan kondisi peserta didik dan adanya penyimpangan yang ada pada diri peserta didik menyebabkan kurangnya pelaksanaan pembelajaran Pendidikan Agama Islam. Ibu Novia memaparkan bahwa di SLB Negeri Ciamis materi pembelajaran Pendidikan Agama Islam yang dikembangkan oleh guru dengan bertitik tolak pada kebutuhan masing-masing peserta didik berdasarkan identifikasi. Karena peserta didik memiliki kemampuan yang berbeda. Serta proses perkembangan dan tingkat pencapaian program juga tidak sama antara peserta didik yang satu dengan yang lainnya, maka pemilihan dan modifikasi materi pembelajaran Pendidikan Agama Islam disesuaikan dengan tingkat perkembangan kemampuan peserta didik dan ketidakmampuan, usia anak serta memerhatikan sumber daya/ lingkungan yang ada. Solusi yang ditawarkan guru dikatakan sudah tepat menyikapi problematika yang ada. Meskipun banyak pembenahan dan masukan dari berbagai pihak yang lebih kompeten. 


\section{BESTARI}

Vol. 17, No. 1, 2020

p-ISSN 1907-1337; e-ISSN 2807-6532

3. Evaluasi Pembelajaran Pendidikan Agama Islam pada Anak Autis di SLBN Ciamis

Evaluasi dalam setiap program sangat penting untuk dilakukan, begitu pula dalam suatu pembelajaran. Evaluasi merupakan sebuah penilaian untuk mengetahui kemajuan dan perkembangan anak. Pada akhir pembelajaran guru melakukan evaluasi kepada anak dengan memberikan pertanyaan sederhana, evaluasi di lakukan untuk mengetahui pencapaian tujuan pembelajaran. Guru membimbing anak, memberi semangat serta motivasi kepada anak yang belum mencapai tujuan pembelajaran. Selain itu guru juga mengevaluasi anak pada saat bermain bersama teman sebayanya serta lingkungan sekitar. Adapun evaluasi yang dilakukan di SLB Negeri Ciamis dilaksanakan dalam tiga kegiatan yakni evaluasi kasus, evaluasi program semester dan tindak lanjut.

a. Evaluasi Kasus

Evaluasi kasus dilaksanakan setiap bulan sekali yang fungsinya mengevaluasi realisasi dari program pembelajaran yang sudah dibuat. Di SLB Negeri Ciamis evaluasi kasus ini diadakan setiap akhir bulan yang diikuti oleh tim guru dan Kepala Sekolah dan orang tua siswa. Dalam evaluasi ini para guru akan berdiskusi dan sharing tentang segala hal mengenai permasalahan, kendala, kegagalan maupun keberhasilan program pembelajaran anak autis yang sudah dilakukan selama satu bulan. Kepala Sekolah selaku penanggung jawab akan meminta laporan kapada guru mengenai pertanggung-jawaban pelaksanaan program pembelajaran.

Pada saat evaluasi kasus guru PAI akan melaporkan tentang penilaian harian masing- masing anak. Penilaian harian menilai aktivitas anak berkaitan dengan instruksi yang diberikan guru sesuai dengan materi kategori kemampuan anak yang tertera pada program pembelajaran. Jika terjadi tidak ada perkembangan kemajuan pada anak selama proses pembelajaran satu bulan maka akan didiskusikan bersama seluruh tim guru dan dicari jalan keluarnya. Hambatan ini kadang bisa saja bukan dari anak autis, tetapi dari guru yang kurang trampil menangani kasus-kasus tertentu sehingga perlu sharing antar guru yang mungkin pernah mengalami kasus yang serupa. Jika hambatan disebabkan oleh anak, pada kasus semacam ini guru akan memanggil orang tua anak autis untuk berdiskusi apa yang sudah dilakukan orang tua di rumah berkaitan dengan hambatan dan kemajuan yang dirasakan orang tua tentang anaknya di rumah, kemudian bersama-sama berdiskusi mencari jalan keluar dan membuat langkah baru yang akan dilakukan orang tua di rumah pada bulan depannya. 
b. Evaluasi Program

Evaluasi program semester dilakukan setiap satu semester atau enam bulan sekali yang bertujuan untuk mengukur atau menilai sejauh mana program yang telah dirancang oleh seluruh guru dapat dikuasai oleh anak autis, mencakup seluruh program pembelajaran di kelas anak autis. Evaluasi program semester ini terdiri atas evaluasi yan menjadi tanggung jawab guru PAI dan evaluasi hasil belajar di kelas yang menjadi tanggung jawab guru kelas.

Hasil evaluasi program semester untuk program pembelajaran PAI akan dilaporkan kepada orang tua dalam bentuk laporan hasil belajar yang lengkap selama satu semester, dalam arti guru PAI akan mendeskripsikan seluruh pelaksanaan program dan hasil yang dicapai anak oleh dalam bentuk narasi. Hasil program semester untuk pembelajaran di kelas akan dilaporkan dalam bentuk raport dan laporan hasil belajar yang dideskripsikan dalam bentuk narasi. Dengan membaca laporan hasil belajar anak ini diharapkan orang tua akan mendapatkan gambaran yang komprehensif mengenai hasil belajar anaknya selama satu semester.

c. Tindak Lanjut

Tahap follow up atau tindak lanjut dilakukan dengan melihat hasil evaluasi program semester. Berdasarkan hasil evaluasi tersebut guru PAI maupun guru kelas akan menentukan program atau langkah selanjutnya. Langkah yang ditempuh adalah apabila program sudah dikuasai anak, dilanjutkan pada program kemampuan berikutnya dengan tetap memperhatikan pada kemampuan yang sudah dikuasai harus tetap dipelihara dan dijaga dengan cara kemampuan-kemampuan yang sudah dikuasai tersebut harus tetap dilakukan oleh anak. Apabila program belum dikuasai oleh anak, akan dilakukan peninjauan kembali atau pengkajian terhadap faktor penyebab. Setelah dilakukan pengkajian, program akan diulangi lagi pada semester berikutnya dengan melakukan perbaikan. Bila ternyata kemampuan anak memang tidak memungkinkan, maka akan mengganti program yang lebih memungkinkan dicapai oleh anak autis. Bagi anak yang sudah menguasai dan memiliki kemampuan dasar seperti kemampuan dasar akademik, kemampuan dasar bersosialisasi, kemampuan berkomunikasi dan perilaku anak sudah dapat dikendalikan, anak autis yang ada di SLB Negeri Ciamis ini akan diintegrasikan ke sekolah yang sesuai dengan tingkat kemampuannya atau ke sekolah reguler yang mengadakan program pendidikan inklusi.

Evaluasi tidak dapat dipisahkan dengan penilaian, karena setiap 


\section{BESTARI}

Vol. 17, No. 1, 2020

p-ISSN 1907-1337; e-ISSN 2807-6532

evaluasi dilakukan pasti ada nilainya dan hal itu dilakukan untuk mengetahui apakah siswa tersebut telah mencapai ketuntasan yang ditetapkan atau belum. Standar penilaian dan nilai kriteria ketuntasan minimum (KKM) ditetapkan oleh masing-masing sekolah.

Peneliti melakukan wawancara dengan kepala sekolah mengenai kriteria ketuntasan minimum. berikut penuturannya: "Untuk masalah kriteria ketuntasan minimum (KKM) sepenuhnya saya serahkan kepada guru kelas dan guru bidang studi”.

Evaluasi pembelajaran Pendidikan Agama Islam (PAI) yang dilaksanakan di SLB Negeri Ciamis tidak berbeda dengan evaluasi pembelajaran Pendidikan Agama Islam (PAI) yang dilaksanakan di sekolah umum lainnya, hanya saja cara pelaksanaannya yang sedikit berbeda.

Peneliti melakukan pengamatan evaluasi pembelajaran Pendidikan Agama Islam (PAI) yaitu kegiatan ulangan harian dan ulangan tengah semester (UTS). Ulangan harian dan ulangan tengah semester dilakukan secara tertulis dan dilaksanakan di kelas. Pada pelaksanaan evaluasi pelajaran Pendidikan Agama Islam (PAI) khusus untuk siswa autis sebelum ulangan harian dan ulangan tengah semester dilaksanakan, guru memberikan contoh soal ulangan sebagai bahan latihan di rumah sebelum ulangan harian dan ulangan tengah semester dilaksanakan. Kemudian siswa autis ini dibantu oleh orang tua mereka dalam mengerjakan latihan contoh soal ulangan. Ketika ulangan harian dan ulangan tengah semester dilaksanakan, siswa masih mendapatkan arahan dari guru pendamping mereka dalam mengerjakan soal ulangan yang diberikan oleh guru.

Berdasarkan uraian di atas, dapat disimpulkan bahwa evaluasi pembelajaran PAI di SLB Negeri Ciamis tidak berbeda dengan evaluasi pembelajaran PAI di sekolah umum lainnya. Hanya saja dalam pelaksanaannya diperlukan perhatian dan kesabaran yang luar biasa bagi guru mata pelajaran Pendidikan Agama Islam (Bapak Ayi Sulaeman) dan guru pendamping khusus (Ibu Novia Alfiatul Fiqri) agar tujuan pembelajaran dapat dicapai baik bagi siswa autis.

Hasil pembelajaran PAI menunjukan bahwa anak-anak autis mengalami perkembangan/kemajuan dalam menjalankan ritual keagamaan, maupun dalam berperilaku hidup seperti tuntutan agamanya. Hal ini ditunjukan seperti wudhu, shalat, doa-doa harian dan lain-lain. Namun kondisi anak autis yang mempunyai hambatan dalam berbagai aspek, baik aspek fisik, mental dan sosial maka anak autis banyak mengalami kesulitan dalam mencapai hasil belajar PAI dengan optimal. 


\section{SIMPULAN}

Berdasarkan penjelasan yang penulis paparkan tersebut, pembahasan tentang implementasi pembelajaran Pendidikan Agama Islam pada anak autis di Sekolah Luar Biasa Negeri Ciamis dapat diambil kesimpulan sebagai berikut: (1) Perencanaan pembelajaran di Sekolah Luar Biasa Negeri Ciamis meliputi segala aspek penunjang terlaksananya proses pembelajaran. Proses pembelajaran Pendidikan Agama Islam pada anak autis di sekolah Sekolah Luar Biasa Negeri Ciamis mengikuti kurikulum 2013 dengan modifikasi guru. Materi yang disampaikan ditekankan pada materi yang bersifat praktis dengan menggunakan berbagai metode sesuai dengan kebutuhan peserta didik. Proses pembelajaran yang berpedoman pada komponen pendidikan, yaitu: tujuan, pendidik, peserta didik, kurikulum, materi, metode dan evaluasi, karena kesemua komponen tersebut sebagai tolak ukur dalam penyesuaian kemampuan anak tersebut, sehingga tujuan pembelajaran yang dinginkan bisa tercapai. Pada tahap perencaan pembelajaran guru juga mempersiapkan perangkat pembelajaran, yaitu silabus dan RPP. (2) Pelaksanaan pembelajaran PAI meliputi kegiatan pendahuluan atau apersepsi, kegiatan inti, dan kegiatan penutup. Alokasi waktu pelaksanaannya yaitu 2 jam pelajaran (2x35 menit) dan dilaksanakan setiap hari Kamis pada pukul 07.30 sampai dengan pukul 08.40 WIB. Pelaksanaan pembelajaran PAI pada anak autis lebih menekankan pada pendidikan karakter/ akhlak, dimana siswa dituntut untuk selalu membiasakan diri berdo'a sebelum pelajaran dimulai, melaksanakan wudhu dan shalat berjama'ah di mesjid, mengucap salam dan mencium tangan/ salim kepada guru ketika di sekolah. Adapun metode pembelajaran yang digunakan beragam, disesuaikan dengan kebutuhan peserta didik. Problem pembelajaran PAI pada anak autis tidak hanya berasal dari siswa, tapi juga dari guru. Kurangnya kreatifitas guru, tipe anak yang berbeda-beda, kesulitan dalam menjelaskan materi yang abstrak serta keterbatasan sarana yang ada di sekolah. Adapun upaya yang dilakukan sekolah terutama oleh guru pengampu mata pelajaran PAI selama ini antara lain adalah: untuk menanggulangi masalah anak autis yang tidak bisa berfikir yang bersifat abstrak, guru memberikan materi yang sesuai dengan kemampuan siswa serta memberikan materi yang ringan, upaya dalam mengatasi kreatifitas guru, guru diberikan pelatihan-pelatihan serta mengikuti seminar-seminar. Keterbatasan sarana prasarana guru menggunakan media visual dan mempraktikan langsung diluar kelas. (3) Adapun evaluasi yang dilakukan di SLB Negeri Ciamis dilaksanakan dalam tiga kegiatan yakni evaluasi kasus, evaluasi program semester dan tindak lanjut. Evaluasi yang dilakukan berpedoman pada kemandirian anak dalam mengerjakan tugas. Sedangkan standar penilaian dan nilai kriteria ketuntasan minimum (KKM) ditetapkan oleh sekolah. 


\section{DAFTAR PUSTAKA}

Bonnice, Sherry. 2009. Anak Yang Tersembunyi. Klaten: PT Intan Sejati.

Daradjat, Zakiah. 1996. Ilmu Pendidikan Islam. Jakarta: Bumi Aksara.

Kurniati, Lina. 2012. Konsep Dasar Perkembangan Komunikasi \& Interaksi Anak Autis. Bandung: PPPPTK \& PLB.

Maulana, Mirza. 2014. Anak Autis: Mendidik Anak Autis dan Gangguan Mental Lain Menuju Anak Cerdas dan Sehat. Jogjakarta: Kata Hati.

Mulyadi, Kesno \& Sutadi, Rudy. 2014. Autism is Curable Benar, Autisme Dapat Disembuhkan. Jakarta: PT Elex Media Komputindo.

Nurhalim, K. 2014. Strategi Pembelajaran Pendidikan Non Formal. Semarang: UNNES Press.

Prasetyono. 2008. Serba-Serbi Anak Autis. Yogyakarta: Diva Press.

Ramayulis. 2005. Metodologi Pendidikan Agama Islam. Jakarta: Kalam Mulia.

Sukmadinata, Nana Syaodih. 2006. Metode Penelitian Pendidikan. Bandung: PT Remaja Rosdakarya.

Suryana, Agus. 2004. Terapi Autisme: Anak Berbakat dan Anak Hiperaktif. Jakarta: Progres.

Tafsir, Ahmad. 2001. Ilmu Pendidikan Dalam Prespektif Islam. Bandung: PT. Remaja Rosdakarya.

Undang-undang RI No 20 tahun 2003. 2013. Tentang Sistem Pendidikan Nasional. Bandung: Fokus Media.

Undang-Undang RI No.11 Tahun 1980. 1989. Sistem Pendidikan Nasional. Jakarta: Gajahyana Pres.

Yatim, Faisal. 2003. Autisme Suatu Gangguan Jiwa Pada Anak-Anak. Jakarta: Pustaka Populer Obor.

Yuwono, Joko. 2009. Memahami Anak Autistik (Kajian Teoritik dan Empirik. Bandung: Alfabeta. 
